\title{
PERCEPTION OF PATIENTS REGARDING QUALITY OF HEALTHCARE SERVICES AT PUBLIC AND PRIVATE TERTIARY CARE HOSPITALS
}

\author{
FARRUKH ANSAR ${ }^{1 *}$, HIRA NAVEED $^{2}$, ALMAS KHATTAK ${ }^{1}$, MUHAMMAD SAAD $^{1}$
}

${ }^{1}$ Northwest School of Medicine, Peshawar, Pakistan. ${ }^{2}$ International Islamic University, Islamabad, Pakistan. Email: farrukhanser@gmail.com

Received: 07 March 2021, Revised and Accepted: 12 April 2021

\section{ABSTRACT}

Objectives: Patient satisfaction is a significant marker for estimating the quality of medical services being provided at a clinical facility. It also influences the opportune, proficient, and patient-focused provision of quality medical services.

Methods: Data from 768 outdoor patients were collected from four tertiary care hospitals in Islamabad, Pakistan. Half of the patients were from public sector hospitals, while others were from private hospitals. A self-administered questionnaire (Cronbach's alpha=0.896) was structured for data collection. Using SPSS, descriptive statistics, independent t-test, and Chi-square test were used to analyze data.

Results: Overall, $51.4 \%$ of patients were satisfied with the services provided to them at hospital Outpatient department. Patients who experienced private sector hospitals (74\%) were significantly more satisfied than those who visited the public sector hospitals (29\%) (p<0.001). Gender-wise, female patients were more satisfied (58\%) than male patients (47\%). Insufficient attention of the doctor, the behavior of the supporting staff and inadequate management of disease record were the red flags highlighted by the patients.

Conclusion: The current investigation has shown that quality healthcare is significantly associated with economic conditions; patients' perspective have expressed that the private sector provides satisfactory medical services at a high expense, whereas the public sector is a less expensive alternative but it lags in the provision of high-quality services and patient satisfaction.

Keywords: Patient satisfaction, Quality of health care, Patient satisfaction, Public sector, Private sector.

(C) 2021 The Authors. Published by Innovare Academic Sciences Pvt Ltd. This is an open access article under the CC BY license (http://creativecommons org/licenses/by/4.0/) DOI: http://dx.doi.org/10.22159/ijms.2021v9i3.41334. Journal homepage: https://innovareacademics.in/journals/index.php/ijms

\section{INTRODUCTION}

Quality healthcare may be defined as; provision and assessment of safe, efficient, viable, opportune, and patient-centered services to attain optimal health [1]. The provision of high-quality health services to the public has always been a matter of concern. Because of the complexities of health-care framework, detailed investigation of the needs, available resources, utilization, and distribution lines are important factors to assess the quality of health-care services [2]. In recent years, due to amplified awareness among masses regarding health-care services, their expectations have been raised and patients will to pay more to avail of quality health services thus playing a pivotal role in coercing health providers to upgrade their services to meet the exigency [3].

Patient satisfaction is a significant factor to evaluate the quality of health-care services, as patients are customers in health-care sectors and customers consistently expect excellent service. A patient's insight regarding the health-care service can improve service quality which builds trust between the healthcare provider and patient which in a long run brings about profitability, a safe working environment and advanced healthcare [4]. It has been demonstrated that intangible attributes of services influence the customer's appraisal of the service. Perception of service quality not only leads to patient satisfaction but also helps the management in optimal decision making [5]. As the health-care sector is more of a people-oriented sector; therefore, it should deliver the services as perceived by patients [6]. Patients who are satisfied with their physicians are most likely to have greater treatment compliance compared to unsatisfied patient [7].

Taking into consideration the fact that public and private hospitals have kept different goals in mind when catering to the need of their patients, it is hypothesized that the level of patient satisfaction would be different between the two sectors of healthcare [7]. However, the present study differs from the previous in the context that it magnifies the quality of health-care services provided in the capital region of Pakistan from patients' point of view. This study was aimed to determine the patient's perception toward private and public health-care service providers and to analyze the relative significance of quality measurements in anticipating the patient's satisfaction and participant allegiance.

\section{METHODS}

This cross-sectional descriptive study was conducted among four major hospitals of Islamabad in September 2019. Patients were approached who were present at the Outpatient department (OPD) for elective consultations. A proper written consent according to the guidelines of World Health guidelines was taken from each participant. Only those patients were included in the study that was present at OPD and signed the consent form. In-door and patients with an emergency were excluded from the study. For sample size estimation, Openepi software was used. Keeping the confidence level at $95 \%$, anticipating frequency $50 \%$, absolute precision (margin of error) 5\% and design effect 1 , the calculated sample size was 384 . However, to increase the strength of our sample, we collected the data from 768 individuals, 384 from each private and public sector hospitals.

Trained research assistants approached the patients and explained to them about nature and need of this study and then requested them to take part in the study. Non-randomized convenient sampling technique was used for data collection. Patients were asked to sign the consent form and then a self-administered questionnaire was presented. However, for individuals who could not fill the questionnaire by themselves or did not understand English, a research assistant asked the questions in their native language and filled the questionnaire. 
Our questionnaire comprised four sections, the first section was a consent form, the second section consisted of demographics, and the third section had some baseline yes/no questions while the fourth section comprised of a scale utilized for investigating the patients' perception regarding health services. The scale comprised 12 questions on a Likert scale having five options, 1-strongly agree 2-agree, 3-neither agree nor disagree, 4-disagree, and 5-strongly disagree, with a maximum score of five in each question. According to the scale, the higher the score more dissatisfied a patient is, while lower scores meant that patient is satisfied with the provided services. Maximum achievable score on the scale was 60 , while the least possible score was 12 . The overall mean score was found to be 27 , so those who scored $<27$ were grouped as satisfied patients and those who scored 28 and above were classified as dissatisfied patients. The scale was developed from the literature available in the previous studies used for the same purpose. The scale was developed and a pilot study was carried out to test the reliability of the scale. Cronbach's alpha for the 12 item questionnaire (scale) was found to be 0.896 (89.6\%).

The data were entered in the SPSS version 23.0 IBM INC, USA Frequencies and percentages were measured for the categorical variables. Independent t-test was used to calculate and compare mean scores while Chi-square test was done for cross-tabulation. We ran statistical analysis at keeping 95\% confidence interval and 5\% p-value.

\section{RESULTS}

In the current study, 814 patients were approached to participate in the study but 46 people refused to do. Hence, the response rate was almost $94 \%$. Among total study population, the majority of the participants were male patients (61\%). Mean age of participants was $47 \pm 9$ years. Among the total of 768 patients who agreed to participate in this survey, half of them were interviewed at public hospitals while others were from private hospitals. About $48.1 \%$ of patients had at least a bachelors' degree in varying disciplines. Patients having primary, middle, matriculation, and intermediate education were $8 \%, 6.7 \%$, $17.4 \%$, and $18.8 \%$, respectively. Less than $1 \%$ of patients did not have any formal education. Majority of participants (72\%) were residents of the urban city while others belonged to rural areas.

The mean satisfaction score calculated among all patients according to the designed scale was $27 \pm 9$. However, the mean satisfaction score among patients who visited public sector hospitals was $32 \pm 9$ while mean satisfaction among patients of the private medical sector was $21.4 \pm 5(p<0.05)$. Table 1 shows the mean scores of each question regarding patient satisfaction covering many aspects.

According to the scale used in the current study, overall $51.4 \%$ of patients were satisfied with the services provided to them at hospital OPDs. Table 2 shows the response of the patients regarding basic facilities available in clinical settings. Our results have shown that patients who experienced private sector hospitals were significantly more satisfied than those who visited the public sector hospitals $(\mathrm{p}<0.001)$. Among the private sector $74 \%$ of the patients were satisfied with the provision of healthcare services whereas only $29 \%$ of the patients were satisfied who visited the public sector hospitals. Similarly, female patients were more satisfied $(58 \%)$ than male patients $(47 \%)$. First-time visitors seemed to be less satisfied (42\%) than those patients who regularly visit the hospital (55\%). We also found out that those patients who belonged to urban areas were more satisfied (54\%) than patients who were from rural areas (44\%). Table 3 shows detailed cross-tabulation of demographic characteristics with satisfied and dissatisfied patients.

About $73 \%$ and $77 \%$ of the patients from public and private hospitals were satisfied with the consultancy hours provided by the doctors. Besides, $100 \%$ of patients from private sector hospitals agreed that mental health is as important as physical health and in case of any mental ill-being; a doctor should be consulted whereas $89 \%$ of patients from public sector patients agreed with the above statement. Patients were also told that the health budget of Pakistan is $<5 \%$ of the total GDP, so more resources should be allocated to the health sector or not. About
Table 1: Mean scores of individual question according to public and private sector

\begin{tabular}{|c|c|c|c|c|}
\hline Questions & Sector & $\begin{array}{l}\text { Mean } \\
\text { score }\end{array}$ & $\begin{array}{l}\text { Std. } \\
\text { error } \\
\text { mean }\end{array}$ & p-value \\
\hline \multirow{2}{*}{$\begin{array}{l}\text { How much you are satisfied } \\
\text { from the process of booking } \\
\text { and registration? }\end{array}$} & Public & $2.68 \pm 1.06$ & 0.054 & \multirow[t]{2}{*}{$<0.05$} \\
\hline & Private & $1.61 \pm 0.48$ & 0.025 & \\
\hline \multirow{2}{*}{$\begin{array}{l}\text { Was duty doctor polite and } \\
\text { gentle and overall behavior? }\end{array}$} & Public & $2.20 \pm 1.02$ & 0.052 & \multirow[t]{2}{*}{$<0.05$} \\
\hline & Private & $1.64 \pm 0.48$ & 0.024 & \\
\hline \multirow{2}{*}{$\begin{array}{l}\text { Doctor listened to all } \\
\text { complaints, examines } \\
\text { properly and answered all } \\
\text { relevant queries. }\end{array}$} & Public & $2.29 \pm 1.05$ & 0.054 & \multirow[t]{2}{*}{$<0.05$} \\
\hline & Private & $1.47 \pm 0.63$ & 0.032 & \\
\hline \multirow{2}{*}{$\begin{array}{l}\text { Doctor properly guided about } \\
\text { medication, side effects and } \\
\text { required diet. }\end{array}$} & Public & $2.49 \pm 1.18$ & 0.060 & \multirow[t]{2}{*}{$<0.05$} \\
\hline & Private & $1.47 \pm 0.61$ & 0.031 & \\
\hline \multirow{2}{*}{$\begin{array}{l}\text { Doctor dealt with respect and } \\
\text { protected my privacy and } \\
\text { dignity. }\end{array}$} & Public & $3.08 \pm 1.23$ & 0.063 & \multirow[t]{2}{*}{$<0.05$} \\
\hline & Private & $1.73 \pm 0.73$ & 0.038 & \\
\hline \multirow{2}{*}{$\begin{array}{l}\text { Overall hospital and clinic } \\
\text { was neat and clean. }\end{array}$} & Public & $2.65 \pm 1.23$ & 0.063 & \multirow[t]{2}{*}{$<0.05$} \\
\hline & Private & $1.29 \pm 0.48$ & 0.025 & \\
\hline \multirow{2}{*}{$\begin{array}{l}\text { Proper seating was offered in } \\
\text { both clinic and waiting area. }\end{array}$} & Public & $2.69 \pm 1.18$ & 0.060 & \multirow[t]{2}{*}{$<0.05$} \\
\hline & Private & $1.29 \pm 0.48$ & 0.025 & \\
\hline \multirow{2}{*}{$\begin{array}{l}\text { Supporting staff was friendly } \\
\text { and gentle. }\end{array}$} & Public & $2.67 \pm 1.25$ & 0.064 & \multirow[t]{2}{*}{$<0.05$} \\
\hline & Private & $1.50 \pm 0.65$ & 0.033 & \\
\hline \multirow{2}{*}{$\begin{array}{l}\text { The building was spacious, } \\
\text { ventilated and big enough for } \\
\text { the available patients. }\end{array}$} & Public & $2.81 \pm 1.28$ & 0.066 & \multirow[t]{2}{*}{$<0.05$} \\
\hline & Private & $2.21 \pm 1.33$ & 0.068 & \\
\hline \multirow{2}{*}{$\begin{array}{l}\text { Were you satisfied from the } \\
\text { medical store; prices and } \\
\text { behavior of the staff? }\end{array}$} & Public & $3.25 \pm 1.25$ & 0.064 & \multirow[t]{2}{*}{$<0.05$} \\
\hline & Private & $2.73 \pm 1.24$ & 0.063 & \\
\hline \multirow{2}{*}{$\begin{array}{l}\text { Were you satisfied from } \\
\text { the laboratory and other } \\
\text { investigations department; } \\
\text { prices and behavior of the } \\
\text { staff? }\end{array}$} & Public & $2.96 \pm 1.22$ & 0.062 & \multirow[t]{2}{*}{$<0.05$} \\
\hline & Private & $2.22 \pm 1.15$ & 0.059 & \\
\hline \multirow{2}{*}{$\begin{array}{l}\text { Record of your disease was } \\
\text { properly maintained and } \\
\text { updated on each visit? }\end{array}$} & Public & $3.15 \pm 1.28$ & 0.065 & \multirow[t]{2}{*}{$<0.05$} \\
\hline & Private & $2.31 \pm 1.02$ & 0.052 & \\
\hline
\end{tabular}

$73 \%$ of the patients from public sector and $99 \%$ from private sector were in favor of increasing the health budget.

\section{DISCUSSION}

The current study is the first of its kind to cover multiple centers and a large sample to measure the satisfaction of patients in the capital city of Pakistan. The questionnaire was designed tactically to cover all major aspects regarding patient satisfaction. Our response rate (94\%) is comparable to the response rate (91.2\%) of a study done in Saudi Arabia [8] regarding inpatients satisfaction and (92.2\%) of the study done in Karachi [9].

Hospitals in the public sector are considered less open to the development and upgradation of basic facilities [10]. Environmental hazards, front desk reception, OPD ticketing, and payments methods and ignorance of paramedical staff are the factors usually reported in different studies and collectively responsible for the decline in patient satisfaction level $[11,12]$. The results of our study demonstrated that in public sector hospitals $55.53 \%$ of patients were satisfied with the basic facilities provided by hospitals whereas in the private sector $73.2 \%$ of patients were satisfied. A previous multi-centered study conducted in the capital city of Pakistan demonstrated that comparatively, patients were more satisfied at private health-care centers than public hospitals [7]. Similarly, a study conducted in Peshawar also reported that patients who visited private hospitals were significantly more satisfied than the ones who experienced the public hospitals [13]. Another national study based on novel grey relational analysis models and the Hurwicz criteria 
Table 2: Baseline questions regarding basic facilities

\begin{tabular}{|c|c|c|c|}
\hline Baseline questions & Overall & Public sector & Private sector \\
\hline Is it your first visit to & Yes $(27.7 \%)$ & Yes (36.9\%) & Yes (18.4\%) \\
\hline this hospital? & No $(72.3 \%)$ & No $(63.1 \%)$ & No $(81.6 \%)$ \\
\hline Are you familiar with & Yes $(88.2 \%)$ & Yes (79.1\%) & Yes (97.3\%) \\
\hline this hospital? & No $(11.8 \%)$ & No $(20.9 \%)$ & No $(2.7 \%)$ \\
\hline Did you asked & Yes (26.9\%) & Yes (15.1\%) & Yes (38.8\%) \\
\hline $\begin{array}{l}\text { someone about } \\
\text { reputation of the } \\
\text { doctor before } \\
\text { consultation? }\end{array}$ & No $(73.1 \%)$ & No $(84.9 \%)$ & No $(61.2 \%)$ \\
\hline Doctor's name, & Yes $(76.6 \%)$ & Yes $(66.6 \%)$ & Yes (86.7\%) \\
\hline $\begin{array}{l}\text { qualifications, } \\
\text { registration number } \\
\text { and designation were } \\
\text { properly written } \\
\text { outside the clinic. }\end{array}$ & No $(23.4 \%)$ & No $(33.4 \%)$ & No $(13.3 \%)$ \\
\hline Were you satisfied & Yes $(80.4 \%)$ & Yes $(66$ & Yes $(94.5 \%)$ \\
\hline $\begin{array}{l}\text { from the service } \\
\text { provided by reception } \\
\text { desk? }\end{array}$ & No $(19.6 \%)$ & No $(33.6 \%)$ & No $(5.5 \%)$ \\
\hline Getting an OPD & Yes (54.9\%) & Yes (55.2\%) & Yes (54.6\%) \\
\hline $\begin{array}{l}\text { ticket was easy and } \\
\text { convenient? }\end{array}$ & No $(45.1 \%)$ & No $(44.8 \%)$ & No $(45.4 \%)$ \\
\hline The waiting area & Yes (78.7\%) & Yes $(5$ & Yes $(100 \%)$ \\
\hline $\begin{array}{l}\text { is comfortable for } \\
\text { patients? }\end{array}$ & No $(21.3 \%)$ & No $(42.5 \%)$ & No ( $0 \%$ ) \\
\hline Pure and clean & Yes $(72.5 \%)$ & Yes $(55.9 \%)$ & Yes (89.1\%) \\
\hline $\begin{array}{l}\text { drinking water was } \\
\text { available? }\end{array}$ & No $(27.5 \%)$ & No $(44.1 \%)$ & No $(10.9 \%)$ \\
\hline Are you satisfied with & Yes $(73.3 \%)$ & Yes (67.1\%) & Yes $(79.4 \%)$ \\
\hline $\begin{array}{l}\text { overall service outside } \\
\text { the doctor's room? }\end{array}$ & No $(26.7 \%)$ & No $(32.9 \%)$ & No $(20.6 \%)$ \\
\hline
\end{tabular}

Table 3: Cross-tabulation of satisfied and dissatisfied patients with demographics

\begin{tabular}{lllll}
\hline Characteristic & $\begin{array}{l}\text { Satisfied } \\
\text { patients } \\
\text { n=395 }\end{array}$ & $\begin{array}{l}\text { Dissatisfied } \\
\text { patients } \\
\text { n=373 }\end{array}$ & $\begin{array}{l}\text { Pearson } \\
\text { Chi- } \\
\text { square }\end{array}$ & p-value \\
\hline $\begin{array}{l}\text { Public sector } \\
\text { Private sector }\end{array}$ & $\begin{array}{l}111 \\
284\end{array}$ & $\begin{array}{l}273 \\
100\end{array}$ & 156 & $<0.001$ \\
$\begin{array}{l}\text { Male } \\
\text { Female }\end{array}$ & 222 & 247 & 9 & 0.009 \\
$\begin{array}{l}\text { First-time } \\
\text { Visitor }\end{array}$ & 90 & 125 & & \\
$\begin{array}{l}\text { Follow-up } \\
\text { visitor }\end{array}$ & 305 & 250 & 9 & 0.002 \\
$\begin{array}{l}\text { Urban resident } \\
\text { Rural resident }\end{array}$ & 93 & 123 & & \\
\hline
\end{tabular}

also bolsters our results by showing the same trend [14]. Middle Eastern and European studies also provided evidence that patients who were consulted at private hospitals were happier and satisfied in almost all domains of health-care services than those patients who were given health-care services at government hospitals $[15,16]$. It is proposed by the researchers that private hospitals are more profit-oriented and to maintain and grow business, they work on understanding the needs and requirements of the patients and carefully develop adequate policies to meet the expectations of the patients [10].

The currentstudy has depicted that overall female patients were relatively more satisfied than male patients; a similar trend was observed in an investigation led at two tertiary care hospitals in Lahore [17]. Another intriguing result of the investigation expresses that patients who routinely visit the clinic for follow-ups were more satisfied than $1^{\text {st-time }}$ visitors. There might be a reason that regular visitors are more familiar with the healthcare system and they comprehend the inadequacies. A Korean report likewise had comparable results by inferring that patients who visit the hospital regularly were more fulfilled than the individuals who once in a while visit a medical care center [18].

Overall $51.4 \%$ of the patients from both the public and private sector were satisfied with the provision of health-care services, this represents that almost half of the patients who are consulted at hospitals goes unsatisfied which is quite vexatious. Another national study from Karachi showed that almost $65 \%$ of the patients were satisfied in a multi-centered setting [9]. An Ethiopian study also demonstrated that $46 \%$ of the total patients were satisfied with the services they received [19]. Although, an investigation from Iran exhibited that 83\% of their sample population was satisfied with the services provided at a tertiary care hospital [20].

While determining the satisfaction level of patients at OPD setting, mostly the factors which are focused includes the behavior of the doctors at OPDs, the avoidance of doctor to inform and guide patients about their disease, facilities outside the clinic, environment, and behavior of supporting staff is also observed in other parts of the world [21]. The doctor-patient relationship and communication have a direct impact on a patient's health [11]. In the current study, significant difference was found between the behavior of doctors at public and private health-care centers. According to the mean scores calculated through a structured questionnaire, it was indicated that at public hospitals patients were less satisfied with the doctor regarding politeness, behavior, examination, listening to the complaints and properly guiding about disease, and medication. However, researchers have found that doctors at public hospitals are burdened by a huge number of patients in a single shift which brings about physical and emotional fatigue, low self-esteem, and a feeling of low self-accomplishment which eventually results in burnout [22]. This reason might be ascribed to the fact that patients at public hospitals cannot grab enough time and attention from a doctor. Studies have shown that informative, supportive and partnership-building communication between physician and patient in OPDs positively influences the patient's health whereas the debilitating and evading nature of correspondence ordinarily leads patients toward precariousness [11]. Findings from a multi-centered investigation led by American analysts revealed that good communication assumes a vital part in the management of OPD patients, their outcomes delineated that those patients with communicative difficulties were at risk of getting a lower quality of healthcare services [23].

A balanced triad of mental, social and physical health is essential for a healthy lifestyle and there is firm evidence that mental wellness is as important as physical wellbeing [24]. In our study sample, $100 \%$ of patients from private sector hospitals concurred that psychological well-being is as significant as physical health and in case of any mental ill-being; a doctor should be consulted whereas only $89 \%$ of patients from public sector patients agreed with the above statement. Although Pakistan is a country where health-care services are provided by both public and private sectors, which is based on an economical premise [25]. Despite the low satisfaction level of patients in public sector hospitals, $27 \%$ of the patients from the public sector hospitals opposed the suggestion of increasing health budget while among private-sector opposing population was only $1 \%$. The reason behind these mystical results may be justified by Kim's analysis, which suggested that higher education is an apparatus for augmenting an individual's rational and economic decision-making quality [26]. This postulate may fit in our case in the fact's light that in the current investigation the graduation rate among patients of private sector hospitals was two-fold of the public patients.

\section{CONCLUSION}

The current study has depicted that quality healthcare is significantly associated with economic resources; patients' perspective stated 
that the private sector provides satisfactory services at a high cost, whereas the public sector is a cheaper option but it lags in the provision of high-quality services and patient satisfaction. In Pakistan, two medical sectors are serving the nation with a different set of protocols as per their resources. Patient health is a sensitive matter which ought to be constantly focused on and managed with extreme care. Legitimate attention should be paid by both government and private sector surveillance organizations to increase the quality of health care and patients concerns, particularly regarding physician-patient communication, supporting staff, and healthcare facility's environment should be resolved. There is also a need to allocate more resources in the health-care sector so that the system could be forestalled from overburdening and every patient could be provided with quality healthcare.

\section{ACKNOWLEDGMENTS}

The authors wish to acknowledge to all the patients and their attendants for their gracious cooperation in this projects.

\section{AUTHORS' CONTRIBUTION}

All the authors have contributed equally in the research.

\section{CONFLICTS OF INTEREST}

All authors declared that no conflicts of interest exist.

\section{FUNDING}

This is a non-funded project.

\section{REFERENCES}

1. Allen-Duck A, Robinson JC, Stewart MW. Healthcare quality: A concept analysis. Nurs Forum 2017;52:377-86.

2. Steinwachs DM, Hughes RG. Health services research: Scope and significance. In: Patient Safety and Quality: An Evidence-Based Handbook for Nurses. Ch. 8. Rockville, MD: Agency for Healthcare Research and Quality; 2008

3. Alijanzadeh M, Zare SA, Rajaee R, Fard SM, Asefzadeh S, Alijanzadeh $\mathrm{M}$, et al. Comparison quality of health services between public and private providers: The Iranian people's perspective. Electron Physician 2016;8:2935-41.

4. Wabo NC, Örtenwall P, Khorram-Manesh A. Hospital evacuation; planning, assessment, performance and evaluation. J Acute Dis 2012;1:58-64

5. Leppäniemi M, Karjaluoto H, Saarijärvi H. Customer perceived value, satisfaction, and loyalty: The role of willingness to share information. Int Rev Retail Distrib Consum Res 2017:27:164-88.

6. Andaleeb SS. Service quality perceptions and patient satisfaction: A study of hospitals in a developing country. Soc Sci Med 2001;52:1359-70.

7. Ghazanfar A, Idress IN, Zia Z, Munir N, Maryam S. Comparison of patient's satisfaction levels in public and private tertiary care centres. J Pak Med Assoc 2017;67:1305-08.

8. Rahim SI, Abumadini M, Wosornu L. Academic job satisfaction questionnaire: Construction and validation in Saudi Arabia. J Fam Community Med 2011;18:1-7.

9. Hussain M, Rehman R, Ikramuddin Z, Asad N, Farooq A. Inpatient satisfaction at different public sector hospitals of a metropolitan city in Pakistan: A comparative cross-sectional study. Hosp Pract (1995) 2018;46:88-96.

10. Kruse FM, Stadhouders NW, Adang EM, Grouewoud S, Jeurissen PT. Do private hospitals outperform public hospitals regarding efficiency, accessibility, and quality of care in the European union? A literature review. Int J Health Plann Manag 2018;33:434-53.

11. Ha JF, Longnecker N. Doctor-patient communication: A review. Ochsner J 2010;10:38-43.

12. Al-Balushi SM, Khan MF. Factors influencing the preference of private hospitals to public hospitals in Oman. Int J Manag Innov Entrep Res 2017;3:67-77.

13. Khattak A, Alvi MI, Yousaf MA, Shah ZA, Turial D, Akhter S. Patient satisfaction a comparison between public and private hospitals of Peshawar. Int J Collab Res Intern Med Public Health 2012;5:713-22.

14. Javed SA, Liu S, Mahmoudi A, Mohammad N. Patients' satisfaction and public and private sectors' health care service quality in Pakistan: Application of grey decision analysis approaches. Int J Health Plann Manage 2019;34:168-82.

15. Anbori A, Ghani SN, Yadav H, Dahir AM, Su TT. Patient satisfaction and loyalty to the private hospitals in Sana'a, Yemen. Int J Qual Health Care 2010;22:310-5.

16. Chari F, Jelastopulu E, Sapountzi-Krepia D, Kaitelidou D, Konstantkopoulou $\mathrm{O}$, et al. Patient satisfaction in public and private hospitals in Cyprus. Scand J Caring Sci 2016;9:781-91.

17. Bokhari T, Manzoor I, Dawood A, Arshad U, Mahmood Z, Ali ZH, et al Gender difference in patient's satisfaction in tertiary care hospitals of Lahore. J Akhtar Saeed Med Dent Coll 2019;1:55-63.

18. Son H, Yom YH. Factors influencing satisfaction with emergency department medical service: Patients' and their companions' perspectives. Jpn J Nurs Sci 2017;14:27-37.

19. Asamrew N, Endris AA, Tadesse M. Level of patient satisfaction with inpatient services and its determinants: A study of a specialized hospital in Ethiopia. J Environ Public Health 2020;2020:2473469.

20. Hajifathali A, Ainy E, Jafari H, Moghadam NM, Kohyar E, Hajikaram S. In-patient satisfaction and its related factors in Taleghani university hospital, Tehran, Iran. J Pak Med Assoc 2008;24:274-77.

21. Kravitz RL, Bell RA, Azari R. Direct observation of requests for clinical services in office practice what do patients want and do they get it? Arch Intern Med 2003;163:1673-81.

22. Patel RS, Bachu R, Adikey A, Malik M, Shah M. Factors related to physician burnout and its consequences: A review. Behav Sci (Basel) 2018;8:98.

23. Street RL, Gordon H, Haidet P. Physicians' communication and perceptions of patients: Is it how they look, how they talk, or is it just the doctor? Soc Sci Med 2007;65:586-98.

24. Ohrnberger J, Fichera E, Sutton M. The relationship between physical and mental health: A mediation analysis. Soc Sci Med 2017;195:42-9.

25. Malik MA, Wasay M. Economics of health and health care in Pakistan. J Pak Med Assoc 2013;63:814-5.

26. Kim HB, Choi S, Kim B, Pop-Eleches C. The role of education interventions in improving economic rationality. Science 2018;362:83-6. 